\title{
POLITIK HUKUM PENANAMAN MODAL ASING SETELAH BERLAKUNYA UNDANG-UNDANG PENANAMAN MODAL 2007 DAN IMPLIKASINYA TERHADAP PENGUSAHA KECIL
}

\author{
Sayidin Abdullah \\ Law Firm Sayidin.Sitompul and Partners Jakarta \\ Email : sayidinabdullah@gmail.com
}

\begin{abstract}
This research aims to describe the choice of law of foreign investment after the entry into force of the Law on Investment and Its Implications for Small Entrepreneurs. By using a normative approach and secondary data, it can be concluded that the regulation and law on the matter of foreign investment in the Investment Law of 2007 do not distinguish between domestic investors and foreign investors. Equal treatment between domestic investors and foreign investors; providing facilities for foreign investors, among others: exemptions or tax relief, repatriation of capital, facilities of permit, and the submission of disputes to international arbitration body. However, the liberalization principles of international trade and foreign investment are contrary to the principles of economic democracy on Article 33 of 1945 Constitution, which requires the fulfillment of the fundamental rights of every individual without exception, while the terms of trade liberalization contained in the WTO are based on the idea of capitalism that restrict the basic rights and only those who are able to compete can enjoy the benefits of international trade provisions of the WTO. It means that Investment Law economically and legally does not provide adequate protection for small entrepreneurs.
\end{abstract}

Keywords: Legal Politics, Investment and Implications.

Penulisan ini bertujuan untuk memaparkan pilihan hukum (politik hukum) penanaman modal asing setelah berlakunya Undang-Undang Penanaman Modal dan implikasinya terhadap pengusaha kecil. Menggunakan pendekatan normatif dengan memanfaatkan data sekunder dapat disimpulkan bahwa pengaturan kebijakan dan hukum penanaman modal asing dalam Undang-Undang Penanaman Modal 2007 tidak membedakan antara penanam modal dalam negeri (PMDN) dan penanam modal asing (PMA). Kebijakan dalam UU Penanaman Modal dengan memperlakukan sama penanam modal, baik dari dalam negara maupun asing yang melakukan 
penanaman modal di Indonesia. Memberikan fasilitas terhadap penanam modal asing, antara lain pembebasan atau keringanan pajak, repatriasi modal, fasilitas perizinan, dan penyerahan sengketa ke badan arbitrase internasional. Akan tetapi, prinsip-prinsip liberalisasi perdagangan internasional dan penanaman modal asing bertentangan dengan prinsip demokrasi ekonomi Pasal 33 UUD 1945, yang menghendaki terpenuhinya hak-hak dasar setiap individu tanpa kecuali, sedangkan ketentuan-ketentuan liberalisasi perdagangan yang terdapat dalam WTO yang dilandasi oleh pemikiran kapitalisme membatasi hak-hak dasar tersebut dan hanya mereka yang mampu bersaing dapat menikmati keuntungan dari ketentuan perdagangan internasional WTO. Artinya, secara ekonomi dan hukum UU Penanaman Modal tidak memberikan perlindungan yang cukup (tidak berpihak) bagi pengusaha kecil.

\section{Kata kunci : Politik Hukum, Penanaman Modal dan Implikasi}

\section{A. Pendahuluan}

Sejak pergantian rezim orde baru kepada rezim orde reformasi tahun 1998 sampai saat ini pertanyaan publik dan para ahli hukum tentang arah politik hukum Indonesia di tengah-tengah "himpitan" tekanan ideologi globalisasi menjadi penting dan relevan dengan bagaimana Indonesia mempersiapkan tatanan hukum (sistem hukum) yang memperhatikan keseimbangan antara kepentingan domestik dan kepentingan hubungan internasional di segala bidang kehidupan bangsa dan bagaimana sistem hukum Indonesia memasukan dua kepentingan yang kontroversial yaitu kepentingan negara di satu sisi dan kepentingan warga negara di sisi lain. UUD 1945 dengan perubahannya merupakan hukum dasar (ground-norm) dan sekaligus merupakan falsafah bangsa Indonesia yang menjadi tonggak tegaknya kedaulatan hukum dan NKRI dalam kehidupan bidang sosial, budaya, ekonomi, politik, dan bidang hukum. ${ }^{1}$

Pembangunan bidang hukum adalah perkembangan perubahan sistem nilai yang dianut bangsa Indonesia mengenai perbuatan yang patut tercela, efisien dan efektif, atau bermanfaat atau tidak bermanfat bagi kehidupan sehari-hari dan masa depan bangsa Indonesia. Ciri perkembangan perubahan sistem nilai dalam suatu sistem hukum adalah ciri utama sekaligus karakteristik khas kemajuan suatu bangsa dalam menyangga kepentingan domestik dan kepentingan hubungan internasional atau salah satu dari keduanya. Pilar penyangga dalam UUD 1945 dan perubahan yang saya

\footnotetext{
1 Romli Atmasasmita, pada Seminar Nasional "Peran Hakim dalam meningkatkan Profesionalisme Hakim Menuju Peradilan Yang Agung", diselenggarakan IKAHI dalam rangka Ulang Tahun IKAHI ke 59 Tanggal 25 April 2012.
} 
pandang penting dan relevan terhadap segala situasi baik kini dan masa mendatang adalah kelima pokok pemikiran (sila-sila) yang tercantum dalam Pancasila dan dalam Pembukaan UUD 1945 dan perubahannya, dan menjiwai seluruh kesatuan batang tubuh tanpa kecuali. Sekalipun UUD 1945 dan perubahannya memberikan celah landasan konstitusional untuk membentuk hukum dalam keadaan darurat (hal ikhwal kegentingan yang memaksa $^{2}$, pembentukannya tetap harus diletakkan dalam kerangka tujuan kepastian hukum, keadilan dan kemanfaatan terbesar untuk perlindungan HAM setiap warga negara bukan sebaliknya.

Persoalan utama dalam perjalanan hidup bangsa Indonesia adalah bagaimana meletakan perkembangan kebutuhan dan aspirasi masyarakat ke dalam program legislasi nasional (prolegnas) di tengah-tengah persaingan global saat ini dan di masa yang akan datang. Penetapan prolegnas tersebut, sejatinya adalah merupakan kebijakan yang cerdas dan mengandung integritas tinggi sebagai bangsa yang dapat menempatkan kepentingan nasional di tengah-tengah hubungan internasional. Kenyataan penetapan prolegnas menunjukan bahwa pemerintah belum memiliki keberanian dan komitmen kuat untuk memegang teguh amanat UUD 1945 dan perubahnya termasuk ketentuan-ketentuan yang mengatur kehidupan bangsa yang bersifat strategis terutama tampak dalam peraturan perundang-undangan dalam bidang ekonomi, sosial dan politik, serta sumber daya alam.

Dalam sistem hukum dan sistem ekonomi suatu negara, terdapat hubungan hukum yang sangat erat dan mempunyai pengaruh timbal balik. Pembaharuan-pembaharuan dasar pemikiran di bidang ekonomi ikut mengubah dan menentukan dasar-dasar sistem hukum yang bersangkutan, penegakkan asas-asas hukum yang sesuai juga akan memperlancar terbentuknya struktur ekonomi yang dikehendaki. Sebaliknya, penegakan asas-asas hukum yang tidak sesuai akan menghambat terciptanya struktur ekonomi yang dicita-citakan. Oleh karena itu, dalam rangka usaha menuju struktur Ekonomi Pancasila, kaidah-kaidah hukum yang melandasinya harus benar-benar mencerminkan nilai-nilai yang dijunjung tinggi oleh Pancasila. ${ }^{3}$

Realisasi dari sistem Ekonomi Pancasila yang tertuang dalam UUD 1945 dan Pancasila terdapat dalam Undang-Undang No. 25 Tahun 2004 tentang Sistem Perencanaan Pembangunan Nasional, Pasal 2 ayat (1) tentang Asas dan Tujuan Pembangunan menyatakan bahwa: pembangunan Nasional diselenggarakan berdasarkan demokrasi dengan prinsip-prinsip kebersamaan, berkeadilan, berkelanjutan, berwawasan lingkungan, serta kemandirian dengan menjaga keseimbangan kemajuan dan kesatuan nasional.

\footnotetext{
${ }^{2}$ Pasal 22 UUD 1945 dan Perubahan.

3 Sunaryati Hartono, Hukum Ekonomi Pembangunan Indonesia, (Bandung: Penerbit Binacipta, 1982), hlm. 6.
} 
Undang-Undang Nomor 17 Tahun 2007 tentang Rencana Pembangunan Jangka Panjang 2005-2025 menyatakan bahwa: ${ }^{4}$

"pembangunan hukum diarahkan untuk mendukung terwujudnya pertumbuhan ekonomi yang berkelanjutan; mengatur permasalahan yang berkaitan dengan ekonomi, terutama dunia usaha dan dunia industri, serta menciptakan kepastian investasi, terutama penegakan dan perlindungan hukum". "pembangunan hukum diarahkan pada makin terwujudnya sistem hukum nasional yang mantap bersumber pada Pancasila dan UUD 1945, yang mencakup pembangunan materi hukum, struktur hukum termasuk aparat hukum, sarana dan prasarana hukum; perwujudan masyarakat yang mempunyai kesadaran hukum dan budaya hukum yang tinggi dalam rangka mewujudkan negara hukum; serta menciptakan kehidupan masyarakat yang adil dan demokratis. Pembangunan hukum dilaksanakan melalui pembaharuan hukum dengan tetap memperhatikan kemajemukan tatanan hukum yang berlaku dan pengaruh globalisasi sebagai upaya untuk meningkatkan kepastian dan perlindungan hukum, penegakkan hukum dan hak asasi manusia".

Hukum harus memegang peranan yang penting bagi sukses tidaknya pelaksanaan suatu rencana pembangunan ekonomi dan pembangunan masyarakat pada umumnya. Hukum harus membuka jalan dan menyalurkan kehendak dan kebutuhan masyarakat kearah tujuan yang dikehendaki. ${ }^{6}$

Konsep hukum sebagai sarana pembaharuan masyarakat merupakan konsep pembangunan hukum yang paling tepat dan relevan sampai saat ini. Seperti dikemukakan oleh Mochtar Kusumaatmadja bahwa fungsi hukum bukan hanya merupakan alat untuk memelihara ketertiban dalam masyarakat tetapi dalam masyarakat yang sedang membangun harus dapat membantu proses perubahan masyarakat itu. ${ }^{7}$

Permasalahannya adalah terletak pada seberapa jauh pembentukan peraturan perundang-undangan baru dalam bidang-bidang hukum yang

4 Indonesia, Undang-Undang tentang Pembangunan jangka Panjang 2005-2025, UU No. 17 Tahun 2007, Bab IV mengenai Arah, Tahapan dan Prioritas Pembangunan Jangka Panjang Tahun 2005-2025, huruf E tentang Reformasi Hukum dan Birokrasi, hlm. 110.

5 Indonesia, Undang-Undang tentang Pembangunan jangka Panjang 2005-2025, UU No. 17 Tahun 2007, Bab IV 1.3 Angka 6 mengenai Mewujudkan Indonesia yang Demokratis Berlandaskan Hukum, hlm. 114.

${ }^{6}$ Sunaryati Hartono, Beberapa Masalah Transnasional dalam PMA di Indonesia, (Bandung: Penerbit Binacipta, 1972), hlm. 8.

7 Mochtar Kusumaatmadja, Fungsi dan Perkembangan Hukum dalam Pembangunan Nasional, Lembaga Penelitian Hukum dan Kriminologi Fakultas Hukum Universitas Padjadjaran, (Bandung: Penerbit Binacipta, 1976), hlm. 1. 
dianggap netral itu telah diantisipasi dampaknya bagi masyarakat secara keseluruhan.

Salah satu tujuan pembentukan pemerintahan negara adalah untuk memajukan kesejahteraan umum. Amanat tersebut antara lain, telah dijabarkan dalam Pasal 33 Undang-Undang Dasar Negara Republik Indonesia Tahun 1945 dan merupakan amanat konstitusi yang mendasari pembentukan seluruh peraturan perundang-undangan di bidang perekonomian. Konstitusi mengamanatkan agar pembangunan ekonomi nasional harus berdasarkan prinsip demokrasi yang mampu menciptakan terwujudnya kedaulatan ekonomi Indonesia. Keterkaitan pembangunan ekonomi dengan pelaku ekonomi kerakyatan dimantapkan lagi dengan Ketetapan Majelis Permusyawaratan Rakyat Republik Indonesia Nomor XVI/MPR/1998 tentang Politik Ekonomi Dalam Rangka Demokrasi Ekonomi sebagai sumber hukum materiil. Dengan demikian, pengembangan penanaman modal bagi usaha mikro, kecil, menengah dan koperasi menjadi bagian dari kebijakan dasar penanaman modal.

Penanaman modal berperan penting untuk meningkatkan kesejahteraan rakyat dan mendatangkan banyak manfaat. Untuk itu Indonesia terus berupaya meningkatkan penanaman modal, yaitu dengan menciptakan iklim investasi yang kondusif di antaranya dengan membentuk UU Penanaman Modal yang baru yaitu UU No. 25 Tahun 2007 yang mulai berlaku pada tanggal 26 April 2007. UU ini dimaksudkan untuk menggantikan UU No. 1 Tahun 1967 dan UU No. 6 Tahun 1968 yang sudah tidak sesuai lagi dengan tantangan dan kebutuhan untuk mempercepat perkembangan perekonomian nasional.

Tujuan penyelenggaraan penanaman modal hanya dapat tercapai apabila faktor penunjang yang menghambat iklim penanaman modal dapat di atasi, antara lain melalui perbaikan koordinasi antarinstansi Pemerintah Pusat dan Daerah, penciptaan birokrasi yang efiesien, kepastian hukum di bidang penanaman modal, biaya ekonomi yang berdaya saing tinggi, serta iklim usaha yang kondusif di bidang ketenagakerjaan dan keamanan berusaha. Dengan perbaikan berbagai faktor penunjang tersebut, diharapkan realisasi penanaman modal akan membaik secara signifikan.

Pembentukan Undang-Undang tentang Penanaman Modal di dasarkan pada semangat untuk menciptakan iklim penanaman modal yang kondusif sehingga Undang-Undang tentang Penanaman Modal mengatur hal-hal yang dinilai penting, antara lain yang terkait dengan cakupan undang-undang, kebijakan dasar penanaman modal, bentuk badan usaha, perlakuan terhadap penanaman modal, bidang usaha, serta keterkaitan pembangunan ekonomi dengan pelaku ekonomi kerakyatan yang diwujudkan dalam pengaturan mengenai pengembangan penanaman modal bagi usaha mikro, kecil, menengah dan koperasi, hak, kewajiban, dan tanggung jawab penanam 
modal, serta fasilitas penanaman modal, pengesahan dan perizinan, koordinasi dan pelaksanaan kebijakan penanaman modal yang di dalamnya mengatur mengenai kelembagaan, penyelenggaraan urusan penanaman modal, dan ketentuan yang mengatur tentang penyelesaian sengketa.

Indonesia adalah Negara anggota WTO yang telah meratifikasi kesepakatan Pendirian WTO dengan UU No. 7 Tahun 2004. Sebagai anggota WTO Indonesia memiliki kewajiban untuk mengharmonisasikan peraturan perundang-undangan dengan kewajiban perdagangan internasional yang telah disepakatinya. Demikian pula UU No. 25 Tahun 2007 tentang Penanaman Modal harus pula harmonis dengan kesepakatan-kesepakatan perdagangan internasional yang telah dilakukan Indonesia dalam rangka kerja sama internasional. Jika kewajiban ini tidak dilakukan maka Indonesia bisa diadukan kedalam penyelesaian sengketa perdagangan WTO oleh negara-negara anggota lain yang berkepentingan.

Berdasarkan latar belakang pemikiran tersebut, bagaimanakah politik hukum penanaman modal asing setelah berlakunya Undang-Undang Penanaman Modal 2007 dan implikasinya terhadap pengusaha kecil ?

\section{B. Pembahasan}

Perkembangan praktek pembentukan hukum dan praktek hukum di Indonesia sejak awal reformasi diketahui dan rasakan sangat transparan "intervensi pengaruh" sistem hukum Amerika Serikat melalui organisasi internasional seperti IMF dan World Bank yang di dominasi oleh para alumni perguruan tinggi terkenal di AS dibandingkan dengan alumni hukum dari daratan Eropa. Sebagai contoh, pembentukan UU Kepailitan, UU Anti Monopoli dan Persaingan Usaha, UU Penanaman Modal, UU Migas, dan UU Kehutanan. Begitu pula pembentukan lembaga baru diluar lembaga konvensional yang telah ada sebelumnya, seperti pembentukan pengadilan niaga. Pola pembentukan hukum dan pelembagaan sebagaimana diuraikan di atas, merupakan wujud nyata dari pengaruh aliran liberalisme dan kapitalisme sebagai landasan politik hukum era globalisasi. ${ }^{8}$

Namun di dalam kenyataannya, arah politik hukum nasional yang dilandaskan pada kekuatan ekonomi pasar dan telah diyakini mendorong pertumbuhan (national growth) terbukti tidak dapat menjamin terciptanya pemerataan (equity) hasil pembangunan ekonomi nasional. Kepercayaan atas kekuatan ekonomi pasar secara berlebihan tanpa kewaspadaan justru telah

\footnotetext{
${ }^{8}$ Untuk memahami plus dan minus tentang Globalisasi, baca dan cermati pandangan Jacques B. Gelinas, dalam karyanya, "Juggernaut Politics":Understanding Predatory Globalization; Zedbooks \& Fernwoods; 2003; Richard Falk, "Predatory Globalization : A Critique"; Polity Press; 2002; dan Joseph Stiglitz,"Globalization and Its Discontent", (2003) dan "Making Globalization Work" (2006).
} 
menimbulkan kepincangan dan kesenjangan antara si miskin dan si kaya yang semakin melebar terutama di Indonesia dengan jumlah penduduk miskin yang telah mencapai $30 \%$ dari total jumlah penduduk sebanyak 250 juta orang. Kondisi tersebut diperparah lagi dalam situasi Indonesia dengan maraknya korupsi sehingga negara mengalami kebocoran sebesar 30\% setiap tahunnya.

Sejak konsensus Washington (1980), ${ }^{9} \quad$ menghasilkan konsep globalisasi internasional maka hegemoni negara super power beralih dari era penggunaan kekuatan militer kepada penggunaan kekuatan ekonomi internasional dalam cita-cita kesejahteraan dunia. Keseimbangan kekuatan saat ini dibedakan dalam dua jenis yaitu "hard power" dan "softpower". Dalam bahasa politik, "soft power" diterjemahkan dengan kalimat sebagai berikut:" If I can get you to want to do what I want, then I do not have to force you to do what you do not want to do".

Kekuatan "soft power" yang dimaksud oleh Nye Jr adalah kemampuan untuk membujuk dan menarik perhatian, dan keduanya sering menuju kepada pengakuan atau peniruan; kekuatan ini terletak pada kebudayaan Amerika Serikat. Kedua kekuatan tersebut (hard and soft power) merupakan modal utama politik AS memasuki era globalisasi karena pemerintah AS menyadari sepenuhnya landasan kekuatan di dunia telah meninggalkan kekuatan militer dan penguasaan (wilayah); tumbuh pesatnya nasionalisme di berbagai belahan dunia; perubahan besar di negara industri maju yaitu fokus pada kesejahteraan (welfare) daripada kemenangan (glory); dan disadari bahwa penggunaan kekerasan membahayakan pencapaian tujuan ekonomi dunia. ${ }^{1}$

Kondisi nyata perkembangan arah ekonomi nasional tersebut di atas jelas memerlukan payung hukum yang searah dengan filsafat kapitalisme barat dengan ekonomi pasar tersebut. Dari sudut inilah kita para ahli hukum dan praktisi hukum yang terlibat dalam pembentukan undang-undang berkaitan dengan bidang ekonomi dan keuangan telah memberikan andil

\footnotetext{
${ }^{9}$ Stiglitz, "Globalization and Its Discontent"; Norton and Company-Paperback; 2003; Hlm. 15-17. Konsensus Washington (Washington Consensus) tahun 1980 adalah konsensus antara IMF, World Bank, dan Departemen Perdagangan Amerika Serikat tentang "Kebijakan yang tepat bagi Negara-Negara Berkembang " yang mencerminkan pendekatan radikal terhadap perkembangan dan stabilisasi Ekonomi.

${ }^{10}$ Joseph P. Nye Jr, The Power of the American Paradox, Oxford University Press; 2002; mengatakan: "Military and economic power are both examples of hard command power that can be used to induce others to change their position. Hard power can rest on inducements (carrot) or threats (sticks)". Sedangkan yang dimaksud dengan "soft power" adalah, "rests on the ability to set the political agenda in a way that shape the preferences of others. The ability to establish preferences tends to be associated with intangible power resources such as an attractive culture, ideology, and institutions".

${ }^{11}$ ibid, Hlm.5-6.
} 
baik secara langsung atau tidak langsung, disadari atau tidak disadari di dalam menciptakan ketimpangan dan kesenjangan sosial antara si kaya dan si miskin tersebut.

Tujuan utama pengaturan nasional dalam perdagangan internasional dan penanaman modal asing adalah untuk menjamin agar keberadaan perusahaan multinasional di Indonesia dapat memberi keuntungan ekonomi dan sosial secara maksimal kepada perekonomian nasional. ${ }^{12}$

Pengaturan nasional berupaya agar produk yang dihasilkan dari penanaman modal asing dapat menembus pasar global juga dapat memenuhi kebutuhan masyarakat. Oleh karena itu, kebijakan dari sudut pandang kepentingan negara penerima modal diharapkan dapat membantu terwujudnya tujuan pembangunan. Namun, persyaratan tersebut oleh perusahaan pemodal asing dipandang sebagai kebijakan yang mengekang atau membatasi kebebasan perusahaan pemodal asing untuk menentukan kebijakan penanaman modal asingnya. ${ }^{13}$ Sebagai reaksi atas adanya persyaratan penanaman modal ini, perusahaan penanam modal asing biasanya meminta kompensasi misalnya berupa insentif penanaman modal, keringanan pajak, atau jaminan perlindungan terhadap penanaman modal yang dituangkan dalam suatu peraturan perundang-undangan (Regulatory Havens). ${ }^{14}$

Peraturan perudang-undangan tersebut diharapkan dapat menyejahterakan negara melalui peluang yang lebih besar bagi penanaman modal asing. Namun, pengaturan nasional ternyata tidak selamanya memberi kesejahteraan seperti yang diharapkan, tetapi sebaliknya menimbulkan kerugian khususnya apabila peraturan perundang-undangan tersebut dibuat oleh negara yang lemah yang tidak memiliki posisi tawar. Dalam prakteknya, posisi tawar selalu berada pada negara maju yang mewakili perusahaan penanam modal asing. ${ }^{15}$

Hukum nasional dan kebijakan-kebijakan dalam penanaman modal asing langsung sangat luas dan beragam dari waktu ke waktu, dari satu tempat ke tempat lain. Dalam membuat peraturan dan kebijakan penanaman

\footnotetext{
${ }^{12}$ Neil Hood and Stephen Young, The Economic of Multinational Enterprise, (Longman, London, 1979), hlm. 244, Lihat juga Thomas L. Brewer and Stephen Young, The Multinational Investment System and Multinational Enterprises, (Oxford: Oxford University Press, 1998), hlm. 24-40.

${ }^{13}$ An Chandrawulan, Hukum Perusahaan Multinasional, Liberalisasi Hukum Perdagangan Internasional dan Hukum Penanaman Modal, cetakan ke-1, (Bandung: Penerbit PT. Alumni, 2011), hlm. 34.

${ }^{14}$ Soi Picciotto, Offshore The State as Legal Fictio; dalam: Mark R. Hampton and Jasson P. Abbott, Offshore Finance Centres and Tax Havens: The Rise of Global Capital, (London: Mac Millan, 1999), hlm. 43.

${ }^{15}$ An An Chandrawulan, op. cit., hlm. 370.
} 
modal asing, pembuat kebijakan paling sedikit dalam kebijakan tersebut harus mencakup tiga permasalahan yaitu: ${ }^{16}$

1. bagaimana menarik penanaman modal asing langsung tanpa mendatangkan atau membuat kerusakan terhadap tabungan mata uang asing domestik dan penggunaan kekayaan alam;

2. bagaimana melindungi hak-hak hukum penanam modal asing dan memberikan perlindungan yang cukup, sementara pada waktu yang bersamaan harus mempertahankan dominasi sebagai negara yang mempunyai kedaulatan/kekuasaan dan meminimalisasi pengaruh negatif dari penanaman modal asing langsung; dan

3. bagaimana membentuk hukum dan sistem pajak yang secara bersamaan dapat mendorong tumbuhnya ekonomi dan sisi lain dapat menarik penanam modal asing serta meningkatkan pendapatan yang cukup sesuai persyaratan penggunaan keuangan negara.

Saat ini hampir semua negara mempunyai hukum dan pengaturan pengawasan terhadap penanam modal asing langsung. Bahkan negara-negara yang mempertahankan kebijakan terbuka terhadap penanaman modal asing langsung pun sekarang mengenakan pembatasan-pembatasan terhadap mengalirnya dan aktivitas penanam modal asing, khususnya dibidang-bidang tertentu misalnya jasa keuangan, telekomunikasi, dan bidang-bidang yang menyangkut kepentingan umum. ${ }^{17}$

\section{Perkembangan Penanaman Modal Sejak Pra Kemerdekaan}

Budaya penanaman modal ini berangkat dari sejarah perdagangan bahwa pada tahun 1025 dan 1275 Portugis dan VOC mencari rempahrempah dan berhasil menemukan daerah penghasil rempah tersebut seperti di Tidore, Malaka, dan lain-lain.

Penanaman modal pertama kali dilakukan di Indonesia melalui kebijakan pemerintah Hindia Belanda yang memperkenankan masuknya modal asing Eropa untuk menanamkan usahanya di bidang perkebunan pada tahun 1870. Terjadinya pengambilalihan hak dan kewajiban badan usaha VOC oleh pemerintah belanda pada tahun 1799 mengakibatkan pemerintah Belanda mulai terjun secara langsung dalam pencarian dan perdagangan bahan-bahan rempah-rempah seperti kopi, pala, cengkeh, lada, dan tebu. Disamping itu, dimungkinkannya penanaman modal di bidang perkebunan di daerah-daerah jajahan seperti di Hindia Belanda. Pemerintah Belanda mulai membuka tanah-tanah pertanian di Indonesia dengan mengeluarkan atauranaturan pertanahan pada tahun 1870 .

\footnotetext{
${ }^{16}$ Ibid.

${ }^{17}$ E.M. Graham and P. Krugman, Foreign Direct Investment in The United States, Institute for International Economics, Washington, 3 rd edition, 1995, hlm. 119.
} 
Peraturan tersebut memberikan keleluasaan kepada investor dari Eropa terutama yang punya hubungan dekat dengan pemerintah Belanda, untuk melakukan usahanya di Indonesia. Sektor pertambangan dan perdagangan tetap dikuasai oleh pemerintah Belanda. Sektor perkebunan karet dan kelapa sawit makin dibuka peluangnya seiring dengan permintaan pasar dunia yang terus meningkat. Untuk itulah pemerintah belanda melindungi perkebunan yang diusahakan langsung untuk menopang struktur tradisional di Indonesia.

Hingga pertengahan abad 19, pemerintah Belanda melakukan segala usaha agar modal asing swasta tidak memasuki sektor pertanian. Namun, pada tahun-tahun terakhir masa sistem tanam paksa yang diterapkan oleh pemerintah kolonial Belanda, mulai tampak gejala perubahan mendasar dalam politik kolonial yang berakibat pada mulai terbukanya peluang bagi investor swasta asing untuk meminta konsesi dalam mengembangkan usahanya. Akibatnya pada tahun 1890 para investor asing eropa telah mendapat izin untuk menyewa (patch) tanah yang belum digarap 25 tahun, juga diizinkan pula mengusahakan tanaman tembakau, kayu manis, dan lainlain.

Perang Dunia II meletus dan jepang menggantikan belanda menduduki Indonesia pada tahun 1942, Kegiatan penanaman modal, khususnya PMA, menjadi turun drastis. Selama pendudukan Jepang (19421945) keadaan penanaman modal terhenti dan mulai menghancurkan struktur perekonomian yang sudah dibangun pemerintah Belanda. Jepang melarang impor bahan mentah dalam skala besar, dan segala bentuk kegiatan yang menunjang perekonomian. Pada masa tersebut sama sekali tidak ada penanaman modal. Semua aktiva milik asing diambil alih Jepang dan baru dikembalikan setelah Jepang kalah tahun 1945 atau setelah berakhirnya seteru Belanda dan Indonesia tahun 1949.

Setelah 17 agustus 1945, secara yuridis Indonesia memulai babak baru dalam mengelola secara mandiri perekonomian negaranya untuk melaksanakan pembangunan nasional, meskipun saat itu untuk penanaman modal masih mengalami kemandekan. Bahkan selama 17 tahun berikutnya Indonesia hanya menjadi Negara pengimpor besar barang modal dan teknologi, dan tidak ada PMA secara langsung (FDI: foreign direct investment). Masalah politik, keamanan dalam negeri, aksi tentara kolonial Belanda yang masih ingin melakukan penjajahan, merupakan faktor-faktor penghambat dalam menata perekonomian Indonesia.

Setelah penyerahan kedaulatan dari Hindia Belanda kepada Indonesia pada tahun 1949, muncul berbagai rencana pembanguan Indonesia untuk melaksanakan pembangunan nasional. Rencana urgensi perekonomian (RUP), yaitu program pendekatan secara pragmatis yang bertujuan untuk meningkatkan industri kecil dan para pengusaha pribumi. Dalam RUP ini 
pembangunan Indonesia juga mengizinkan adanya penanaman modal, termasuk PMA, untuk dapat lebih aktif dalam industri-industri yang tidak begitu penting, asalkan memenuhi syarat dari pemerintah yaitu $51 \%$ sahamnya dimiliki oleh orang Indonesia. Selain itu juga ada pembatasan pada bidang-bidang tertentu dimiliki oleh domestik dan tertutup untuk asing. Kenyataan tidak ada PMA yang masuk. Keadaan ini menimbulkan pertentangan antara kelompok moderat dan radikal di Indonesia. Periode 1950-1957 pemerintah Indonesia menasionalisasi perusahaan-perusahaan yang telah didirikan dalam rangka PMA. Kondisi perekonomian Indonesia terus mengalami kehancuran hingga peristiwa G30S PKI pada tahun 1965.

Hingga peralihan kekuasaan dari rezim orde lama ke orde baru pada 11 Maret 1966, mulailah penataan kembali perekonomian Indonesia dengan menjadwal ulang pelunasan hutang luar negeri, menciptakan mekanisme untuk menanggulangi inflasi, merehabilitasi infrastruktur, mendorong pertumbuhan ekonomi, memperbaiki hubungan dengan luar negeri dalam rangka mencari bantuan pinjaman, dan PMA.

Pendekatan perekonomian yang dilakukan oleh orde baru yang lebih pragmatis telah menunjukan keberhasilan dengan adanya perbaikan sarana dan prasarana ekonomi, menurunnya angka inflasi, infrastruktur yang membaik, dan pertumbuhan ekonomi yang meningkat. Prosedur perizinan investasi pada saat BPKM belum dibentuk yaitu tidak adanya catatan negatif (negative list ini berupa daftar bidang usaha yang tidak boleh dimasuki oleh investor asing). Untuk PMA, pengajuan investasi dinilai oleh menteri teknis dan diajukan kepada presiden untuk memperoleh persetujuan. Untuk PMDN, pengajuan investasi dinilai oleh menteri teknis, Insentif investasi disediakan.

Perubahan kebijakan pada tahun 1971 dan 1973, insentif investasi dikurangi dari tax holiday menjadi skim investasi, BKPM dibentuk dan diberi peran hanya untuk mengkordinasi saja, belum adanya kebijakan satu atap dalam hal prosedur perizinan, dalam hal memperoleh izin investasi , investor harus bolak-balik ke berbagai depatemen teknis dan BKPM, daftar positif untuk investasi dibuat. Daftar positif ini merupakan daftar bidang usaha yang boleh dimasuki oleh investor asing.

Perubahan kebijakan pada tahun 1977, yaitu dibuatnya satu kebijakan investasi, dan BKPM menjadi badan tunggal untuk urusan investasi, BKPM (badan koordinasi penanaman modal/investment coordinating Board) menjadi satu-satunya lembaga yang mengeluarkan kebijakan dan prosedur investasi. BKPM daerah pun dibentuk di tiap propinsi, yang berfungsi menjadi lembaga yang memberikan perizinan investasi di daerah.

\section{Perlakuan Sama terhadap Penanam Modal}

Pemerintah memberi perlakuan yang sama bagi penanam modal dalam negeri dan penanam modal asing dengan tetap memperhatikan kepentingan 
nasional (Pasal 4 ayat (2) UU No. 25 Tahun 2007). Pemerintah memberikan perlakuan yang sama kepada semua penanam modal yang berasal dari negara manapun yang melakukan kegiatan penanaman modal di Indonesia sesuai dengan ketentuan peraturan perundang-undangan (Pasal 6 ayat (1). Namun demikian, perlakuan ini tidak berlaku bagi penanam modal dari suatu negara yang memperoleh hak istimewa berdasarkan perjanjian dengan Indonesia (Pasal 6 ayat (2).

Dalam hukum perdagangan internasional, prinsip ini menuntut tidak adanya perlakuan khusus terhadap barang buatan dalam negeri dan larangan adanya perlakuan diskriminatif berdasarkan asal negara. Barang buatan dalam negeri dan barang asal impor diperlakukan sama, demikian pula bahwa perlakuan terhadap semua negara anggota WTO harus sama tanpa ada negara tertentu yang diperlakukan khusus.

Namun dalam Pasal 6 ayat (2) UU Penanaman Modal merupakan pasal yang menerapkan perlakuan diskriminatif, dengan adanya perlakuan khusus kepada negara-negara tertentu berdasarkan perjanjian dengan Indonesia. Sasaran dari perlakuan khusus ini adalah negara-negara yang terikat perjanjian penanaman modal secara bilateral, regional, maupun multilateral dengan Indonesia.

\section{Pembatasan Bidang Usaha}

UU No. 25 Tahun 2007 tidak membuka seluruh bidang usaha bagi kegiatan penanaman modal asing. Pasal 12 ayat (2) Undang-Undang tersebut menetapkan bahwa bidang usaha yang terkait langsung dengan keamanan negara seperti produksi senjata, mesin, alat peledak, dan peralatan perang dan bidang usaha yang secara eksplisit dalam undang-undang dinyatakan tertutup, tidak dibenarkan bagi penanaman modal asing. Dalam ayat (3) selanjutnya menetapkan bidang usaha yang tertutup bagi penanaman modal asing berdasarkan alasan kesehatan, moral, kebudayaan, lingkungan hidup, pertahanan, dan keamanan nasional, serta kepentingan nasional lainnya.

Lebih lanjut dalam Pasal 12 ayat (5) ditegaskan bahwa pemerintah dapat menetapkan bidang usaha yang terbuka dengan persyaratan berdasarkan kriteria kepentingan nasional, yaitu perlindungan sumber daya alam, perlindungan pengembangan usaha mikro, kecil, menengah dan koperasi, pengawasan produksi dan distribusi, peningkatan kapasitas teknologi, partisipasi modal dalam negeri, serta kerja sama dengan badan usaha yang ditunjuk pemerintah. Pembatasan bidang usaha yang demikian tidak dilarang dalam kesepakatan di bidang perdagangan.

Semua bidang usaha atau jenis usaha terbuka bagi kegiatan penanaman modal, kecuali bidang usaha atau jenis usaha yang dinyatakan tertutup dan terbuka dengan persyaratan berdasarkan Peraturan Pemerintah No. 76 Tahun 2007 dan No. 77 Tahun 2007, maka terdapat 25 bidang-bidang 
usaha yang tertutup untuk penanam modal termasuk penanaman modal asing, 43 bidang-bidang usaha yang dicadangkan untuk mikro, kecil, menengah, dan koperasi, 36 bidang usaha yang harus bermitra, 120 bidang usaha yang diatur besarnya nilai modal asing, 19 bidang usaha yang diatur lokasinya, 25 bidang usaha yang harus memiliki izin khusus, 48 bidang usaha yang modal dalam negeri $100 \%$, dan 22 bidang usaha yang diatur pemilik modal dan lokasinya.

\section{Pembatasan Penggunaan Tenaga Kerja Asing}

Pasal 10 UU No. 25 Tahun 2007 mewajibkan perusahaan penanaman modal dalam memenuhi kebutuhan tenaga kerja untuk mengutamakan tenaga kerja warga negara Indonesia. Perusahaan penanaman modal berhak menggunakan tenaga ahli warga negara asing untuk jabatan dan keahlian tertentu sesuai dengan ketentuan peraturan perundang-undangan. Perusahaan penanaman modal yang memekerjakan tenaga kerja asing diwajibkan menyelenggarakan pelatihan dan melakukan alih teknologi kepada tenaga kerja warga negara Indonesia sesuai dengan ketentuan peraturan perundangundangan.

Pada prinsipnya penggunaan tenaga kerja asing dibatasi pada bidangbidang pekerjaan atau jabatan yang belum dapat diisi oleh tenaga kerja warga negara Indonesia. Pembatasan ini sepintas bertentangan dengan GATS yang mengatur tentang free personal movement yang tidak membatasi penggunaan tenaga kerja asing kedalam kegiatan penanaman modal.

Meskipun ketentuan pembatasan penggunaan tenaga kerja asing tidak bertentangan dengan GATS, peraturan nasional negara-negara anggota (domestic regulations) dibenarkan untuk menetapkan syarat-syarat penggunaan tenaga kerja asing dengan memperhatikan specific of commitment dari negara anggota yang bersangkutan.

\section{Persyaratan Pemberian Fasilitas Penanaman Modal}

UU Penanaman Modal mengatur tentang Fasilitas Penanaman Modal pada Bab X mulai dari Pasal 18 sampai dengan Pasal 24. Secara umum tidak ada ketentuan perdagangan internasional yang melarang pemberlakuan insentif penanaman modal berupa fasilitas penanaman modal. Masalah bisa muncul jika pemberian insentif investasi dikaitkan dengan performance requirement yang bertentangan denganTRIMs Agreement. Menarik untuk diperhatikan dalam Pasal 18 UU PM ini terdapat dua kemungkinan keberatan penanam modal, khususnya penanam modal asing. Pertama, fasilitas penanam modal tidak diberikan kepada semua penanam modal, akan tetapi hanya kepada penanaman modal yang memenuhi persyaratan tertentu. 
Bisa saja ketentuan demikian diartikan sebagai ketentuan yang diskriminatif. Kedua, Pasal 18 ayat (3) huruf (j) mengaitkan fasilitas penanaman modal dengan penggunaan produksi dalam negeri. ${ }^{18}$

Persyaratan untuk memperoleh fasilitas penanaman modal sebagaimana diatur dalam Pasal 18 ayat (3) huruf (a) sampai dengan (i) tidak bertentangan dengan ketentuan perdagangan internasional, karena tidak ada ketentuan secara imperatif melarang persyaratan tersebut. Pemberian fasilitas yang dibatasi pada penanaman modal yang memenuhi syarat tertentu semestinya dipandang sebagai konsistensi pemerintah terhadap pandangan yang mengakui bahwa penerapan kebijakan penanaman modal tunduk pada kedaulatan politik Indonesia yang pelaksanaannnya disesuaikan dengan kebutuhan pembangunan ekonomi. Dalam pemaknaan yang demikian, syarat-syarat tersebut adalah bentuk dari kebutuhan pembangunan ekonomi Indonesia pada sektor industri. Masalah seperti ini belum mendapatkan pengaturan yang tegas dan merupakan salah satu agenda kontroversial dalam negosiasi trade and investment.

Pasal 18 ayat (3) huruf (j) yang mengakibatkan fasilitas penanaman modal dengan penggunaan produksi dalam negeri kemungkinan akan mendapat perhatian penanam modal asing. Fasilitas penanaman modal yang demikian dapat berdampak pada perdagangan internasional, karena pemberian fasilitas tersebut di dasarkan pada syarat yang dapat berakibat adanya perbedaan perlakuan antara barang buatan dalam negeri dengan barang impor. Dalam hal ini perlakuan khusus diberikan kepada barang buatan dalam negeri dalam bentuk fasilitas penanaman modal, fasilitas mana tidak diberikan kepada penanam modal yang menggunakan barang impor. Mengingat pasal ini tidak menyaratkan adanya kewajiban menggunakan barang buatan dalam negeri dalam jumlah, nilai , atau persentase tertentu seperti yang dilarang dalam TRIMs Agreement. Tindakan ini merupakan tindakan sukarela tetapi diberikan insentif penanaman modal. Pasal 18 ayat (3) huruf (j) ini berlindung pada argumentasi tidak adanya kewajiban menggunakan barang buatan dalam negeri.

\section{Persyaratan Penanaman Modal}

Pasal 12 ayat (4) UU Penanaman Modal memberikan kewenangan kepada pemerintah untuk menetapkan syarat-syarat penanaman modal pada bidang usaha yang terbuka bagi penanaman modal. Selanjutnya pada ayat (5) ditetapkan kriteria kepentingan nasional yang harus diperhatikan dalam menetapkan persyaratan penanaman modal, yakni perlindungan sumber daya

18 Asmin Nasution, "Penerapan Prinsip Transparansi dalam Undang-Undang Nomor 25 Tahun 2007 tentang Penanaman Modal Kaitannya dengan Domestic Regulation WTO”, (Medan: Tesis Magister Univesitas Sumatera Utara, 2009), hlm. 99. 
alam, perlindungan pengembangan usaha mikro, kecil, menengah dan koperasi, pengawasan produksi dan distribusi, peningkatan kapasitas teknologi, partisipasi modal dalam negeri, serta kerja sama dengan badan usaha yang ditunjuk pemerintah.

WTO (TRIMs Agreement), tetapi tidak melarang persyaratan penanaman modal lainnya seperti kewajiban joint venture, pembatasan pemilikan saham asing, kemitraan dengan UKMK, alih teknologi, dan persyaratan-persyaratan berkenaan dengan upaya melindungi lingkungan hidup. Persyaratan-persyaratan yang demikian termasuk pada noncross border issues yang pelaksanaannnya tergantung pada kebutuhan pembangunan ekonomi negara host country.

Dalam kaitannya dengan GATS, maka harus dipahami bahwa GATS berlaku untuk penanaman modal sektor jasa yang dibatasi oleh pendekatan positive list dan specific of commitment. GATS mewajibkan perlakuan sama berdasarkan prinsip national treatment dan most favour nations. Pendekatan positive list membatasi keberlakuan GATS untuk bidang-bidang usaha yang tercantum dalam commitment negara anggota. Bahkan GATS juga masih membenarkan adanya persyaratan-persyaratan tertentu yang diterapkan kepada penanaman modal asing sepanjang persyaratan tersebut masuk dalam specific of commitment dari negara peserta. ${ }^{19}$

Perlakuan sama dalam sistem perdagangan jasa berlaku pada tahap post establishment stage, yakni setelah perusahaan penanaman modal berdiri atau mendapatkan persetujuan penanaman modal. Dengan demikian, pada saat entry approval (pre-establishment stage), host country masih dibenarkan menetapkan persyaratan-persyaratan penanaman modal yang disesuaikan dengan kebutuhan pembangunan ekonomi suatu negara. Hal tersebut merupakan pemaknaan liberalisasi bertahap dalam bidang penanaman modal sektor jasa.

Dalam penerapan persyaratan penanaman modal, yang harus diperhatikan adalah persyaratan yang ditetapkan tidak masuk dalam kategori performance requirement yang dilarang berdasarkan TRIMs Agreement, dan persyaratan penanaman modal terhadap penanaman modal asing sektor jasa dilakukan berdasarkan specific of commitment Indonesia dalam WTO.

Berdasarkan ketentuan Pasal 32 ayat (4) mengenai Penyelesaian Sengketa dalam bidang Penanaman Modal, bahwa:

"Dalam hal terjadi sengketa di bidang penanaman modal antara Pemerintah dengan penanam modal asing, para pihak akan menyelesaikan sengketa tersebut melalui arbitrase internasional yang harus disepakati oleh para pihak".

19 Asmin Nasution, "Penerapan Prinsip Transparansi dalam Undang-Undang Nomor 25 Tahun 2007 tentang Penanaman Modal Kaitannya dengan Domestic Regulation WTO", (Medan: Tesis Magister Univesitas Sumatera Utara, 2009), hlm. 9. 
Perlakuan terhadap penanaman modal selain perlakuan yang sama dan tidak akan dinasionalisasi pemerintah juga membolehkan penanam modal untuk mengalihkan aset yang dimilikinya kepada pihak yang diinginkan oleh penanam modal sesuai dengan ketentuan perundang-undangan. ${ }^{20}$ Penanam modal juga diberi hak unttuk melakukan transfer dan repatriasi dalam valuta asing antara lain terhadap: ${ }^{21}$

a. modal;

b. keuntungan, bunga bank, deviden, dan pendapatan lain;

c. dana yang diperlukan untuk pembelian bahan baku dan penolong, barang setengah jadi, atau barang jadi atau penggantian barang modal dalam rangka melindungi kelangsungan hidup penanaman modal;

d. tambahan dana yang diperlukan bagi pembiayaan penanaman modal;

e. dana untuk pembayaran kembali pinjaman;

f. royalti atau biaya yang harus dibayar;

g. pendapatan dari perseorangan warga negara asing yang bekerja dalam perusahaan penanaman modal;

h. hasil penjualan atau likuidasi penanaman modal;

i. kompensasi atas kerugian;

j. kompensasi atas pengambilalihan;

k. pembayaran yang dilakukan dalam rangka bantuan teknis, biaya yang harus dibayar untuk jasa teknik dan manajemen, pembayaran yang dilakukan di bawah kontrak proyek, dan pembayaran hak atas kekayaan intelektual; dan

1. hasil penjualan aset yang dialihkan kepada pihak lain.

Penanaman modal asing yang menanamkan modalnya baik yang melakukan perluasan usaha maupun yang melakukan penanaman modal baru di Indonesia akan mendapat fasilitas-fasilitas dari pemerintah dengan syarat sekurang-kurangnya memenuhi salah satu kriteria berikut ini:

a. menyerap banyak tenaga kerja;

b. termasuk skala prioritas tinggi;

c. termasuk pembangunan infrastruktur;

d. melakukan alih teknologi;

e. melakukan industri pionir;

f. berada di daerah terpencil, daerah tertinggal, daerah perbatasan, atau daerah lain yang dianggap perlu;

g. menjaga kelestarian lingkungan hidup;

h. melaksanakan kegiatan penelitian, pengembangan, dan inovasi;

i. bermitra dengan usaha mikro, kecil, menengah atau koperasi; atau

\footnotetext{
${ }^{20}$ Indonesia (1), Undang-Undang tentang Penanaman Modal. UU No. 25, LN No. 67 Tahun 2007, TLN No. 4724, Pasal 8 ayat (1).

${ }^{21}$ Indonesia (1), Pasal 8 ayat (3).
} 
j. industri yang menggunakan barang modal atau mesin atau peralatan yang diproduksi di dalam negeri. ${ }^{22}$

Selain keringanan dan pembebasan perpajakan, penanaman modal asing juga diberikan kemudahan pelayanan dan perizinan untuk memperoleh hak atas tanah, fasilitas pelayanan keimigrasian dan fasilitas perizinan impor. ${ }^{23}$ Semua fasilitas ini tidak berlaku bagi penanaman modal asing yang tidak berbentuk perseroan terbatas. ${ }^{24}$

Bentuk badan usaha bagi penanaman modal asing yang akan menanamkan modalnya di Indonesia harus berbentuk badan hukum perseroan terbatas berdasarkan hukum Indonesia dan berkedudukan di dalam wilayah negara Republik Indonesia. Penanam modal asing yang melakukan penanaman modal dalam bentuk perseoran terbatas dilakukan dengan mengambil bagian saham pada saat pendirian perseroan terbatas, membeli saham dan melakukan cara lain sesuai dengan ketentuan peraturan perundang-undangan. ${ }^{25}$

Sedangkan mengenai bidang usaha bagi penanam modal asing, semua bidang usaha atau jenis usaha terbuka bagi kegiatan penanaman modal, kecuali bidang usaha atau jenis usaha yang dinyatakan tertutup dan yang terbuka dengan persyaratan ditetapkan melalui PP No. 76 dan 77 Tahun 2007 dan PP No.111 Tahun 2007 dan PP No.36 Tahun 2010 yang disusun dalam suatu daftar yang berdasarkan klasifikasi tentang bidang usaha atau jenis usaha yang berlaku di Indonesia yaitu Klasifikasi Baku Lapangan Usaha Indonesia (KBLI) dan/atau International Standard for Industrial Classification (ISIC). ${ }^{26}$

Bidang Usaha yang terbuka bagi Penanam Modal diatur dalam Pasal 12 menyatakan bahwa:

(1) semua bidang usaha atau jenis usaha terbuka bagi kegiatan penanaman modal, kecuali bidang usaha atau jenis usaha yang dinyatakan tertutup dan terbuka dengan persyaratan;

(2) bidang usaha yang tertutup bagi penanam modal asing adalah: a) produksi senjata, mesin, alat peledak, dan peralatan perang; dan b) bidang usaha yang secara eksplisit dinyatakan tertutup berdasarkan undang-undang;

(3) pemerintah berdasarkan Peraturan Presiden menetapkan bidang usaha yang tertutup untuk penanaman modal, baik asing maupun dalam negeri, dengan berdasarkan kriteria kesehatan, moral, kebudayaan,

\footnotetext{
${ }^{22}$ Ibid., Pasal 18.

${ }^{23}$ Ibid., Pasal 21.

${ }^{24}$ Ibid., Pasal 20.

${ }^{25}$ Ibid., Pasal 5 ayat (2) dan (3).

${ }^{26}$ Ibid., Pasal 12 ayat (1).
} 
lingkungan hidup, pertahanan dan keamanan nasional, serta kepentingan nasional lainnya;

(4) kriteria dan persyaratan bidang usaha yang tertutup dan yang terbuka dengan persyaratan serta daftar bidang usaha yang tertutup dan yang terbuka dengan persyaratan masing-masing akan diatur dengan Peraturan Presiden; dan

(5) pemerintah menetapkan bidang usaha yang terbuka dengan persyaratan berdasarkan kriteria kepentingan nasional, yaitu perlindungan sumber daya alam, perlindungan, pengembangan usaha mikro, kecil, menengah dan koperasi, pengawasan produksi dan distribusi, peningkatan kapasitas teknologi, partisipasi modal dalam negeri, serta kerja sama dengan badan usaha yang ditunjuk pemerintah.

Bentuk fasilitas yang diberikan kepada penanam modal berdasarkan Pasal 18 ayat (4) UU No. 25 Tahun 2007 dapat berupa:

a. pajak penghasilan melalui pengurangan penghasilan neto sampai tingkat tertentu terhadap jumlah penanaman modal yang dilakukan dalam waktu tertentu;

b. pembebasan atau keringanan bea masuk atas impor barang modal mesin, atau peralatan untuk keperluan produksi yang belum dapat diproduksi di dalam negeri;

c. pembebasan atau keringanan bea masuk bahan baku atau bahan penolong untuk keperluan produksi untuk jangka waktu tertentu dan persyaratan tertentu;

d. pembebasan atau penangguhan pajak pertambahan nilai atas impor barang modal atau mesin atau peralatan untuk keperluan produksi yang belum dapat diproduksi di dalam negeri selama jangka waktu tertentu;

e. penyusutan atau amortisasi yang dipercepat; dan

f. keringanan Pajak Bumi dan Bangunan, khususnya untuk bidang usaha tertentu, pada wilayah, atau daerah atau kawasan tertentu.

\section{Sistem Pelayanan Terpadu Satu Pintu}

Permasalahan pokok yang dihadapi penanam modal dalam memulai usaha di Indonesia diperhatikan oleh Undang-Undang ini sehingga terdapat pengaturan mengenai pengesahan dan perizinan yang di dalamnya terdapat pengaturan mengenai pelayanan terpadu satu pintu.

Dengan sistem itu, sangat diharapkan bahwa pelayanan terpadu di pusat dan di daerah dapat menciptakan penyederhanaan perizinan dan percepatan penyelesaiannya. Selain pelayanan penanaman modal di daerah, Badan Koordinasi Penanaman Modal diberi tugas mengoordinasikan pelaksanaan kebijakan penanam modal.Badan Koordinasi Penanaman Modal 
dipimpin oleh seorang kepala yang bertanggungjawab langsung kepada Presiden.

Jabaran tugas pokok dan fungsi Badan Koordinasi Penanaman Modal pada dasarnya memperkuat peran badan tersebut guna mengatasi hambatan penanaman modal, meningkatkan kepastian pemberian fasilitas kepada penanam modal, dan memperkuat peran penanam modal. Peningkatan peran penanaman modal tersebut harus tetap dalam koridor kebijakan pembangunannasional yang direncanakan dengan tetap memperhatikan kestabilan makroekonomi dan keseimbangan ekonomi antarwilayah, sektor, pelaku usaha, dan kelompok masyarakat, mendukung peran usaha nasional, serta memenuhi kaidah tata kelola perusahaan yang baik (good corporate governance).

Undang-Undang ini memerintahkan agar Pemerintah meningkatkan koordinasi antarinstansi Pemerintah, antarinstansi Pemerintah dengan Bank Indonesia, dan antarinstansi Pemerintah dengan pemerintah daerah. Koordinasi dengan pemerintah daerah harus sejalan dengan semangat otonomi daerah. Pemerintah daerah bersama-sama dengan instansi atau lembaga, baik swasta maupun Pemerintah, harus lebih diberdayakan lagi, baik dalam pengembangan peluang potensi daerah maupun dalam koordinasi promosi dan pelayanan penanaman modal. Pemerintah daerah menjalankan otonomi seluas-luasnya untuk mengatur dan mengurus sendiri urusan penyelenggaraan penanaman modal berdasarkan asas otonomi daerah dan tugas pembantuan atau dekonsentrasi. Oleh karena itu, peningkatan koordinasi kelembagaan tersebut harus dapat diukur dari kecepatan pemberian perizinan dan fasilitas penanaman modal dengan biaya yang berdaya saing. Agar memenuhi prinsip demokrasi ekonomi, Undang-Undang ini juga memerintahkan penyusunan peraturan perundang-undangan mengenai bidang usaha yang tertutup dan yang terbuka dengan persyaratan, termasuk bidang usaha yang harus dimitrakan atau dicadangkan bagi usaha mikro, kecil, menengah, dan koperasi.

\section{Implikasi Penerapan UU No. 25 Tahun 2007 terhadap Pengusaha Kecil}

Asas Perlakuan Sama dalam Pasal 6 ayat (1) UU No. 25 Tahun 2007 adalah merupakan penerapan Prinsip Perlakuan Sama (National Treatment \& Most Favoured Nations) dalam Prinsip National treatment terdapat pada 3 (tiga) Pasal WTO Agreements yang utama, yaitu Pasal III, khususnya Pasal III: 4 GATT, Pasal XVII GATS, dan Pasal 3 TRIP Agreements. Namun demikian, Prinsip National Treatment yang terkait dengan penanaman modal diatur dalam Pasal III: 4 GATT dan Pasal XVII GATS.

Kewajiban perlakuan nasional adalah ketentuan mengenai nondiskriminasi. Kewajiban ini menekankan prinsip non diskriminasi 
terhadap barang-barang yang dibuat dalam negeri dengan barang-barang impor. Prinsip atau kewajiban ini merupakan bentuk utama dari aturanaturan dan kebijakan perdagangan internasional. Prinsip ini termuat dalam GATT. Tujuannya adalah untuk mencegah praktek-praktek perdagangan pemerintah negara-negara anggota GATT yang berupaya menghindari kewajiban-kewajiban dalam penetapan tarif. ${ }^{27}$

Prinsip national treatment merupakan batu penyangga dalam sistem perdagangan internasional dewasa ini, bersama dengan prinsip most favoured nation, prinsip ini menjamin tidak adanya tindakan diskriminatif diterapkan oleh negara-negara anggota. ${ }^{28}$ Jiwa dari prinsip national treatment adalah adanya perlakuan yang sama oleh suatu negara baik terhadap kepentingannya sendiri maupun terhadap kepentingan negara lain.

Berkaitan dengan mekanisme perdagangan bebas multilateral, prinsip ini melarang negara-negara anggota WTO menerapkan kebijakan yang menyebabkan diskriminasi perlakuan antara produk impor dengan produk buatan sendiri. Dengan kata lain, negara-negara anggota memiliki kewajiban untuk tidak memperlakukan produk-produk impor secara berbeda dengan kebijakan terhadap produk-produk yang sama buatan dalam negeri. ${ }^{29}$ Ruang lingkup berlakunya prinsip ini juga berlaku terhadap semua diskriminasi yang muncul dari tindakan-tindakan perpajakan dan pungutan-pungutan lainnya. Prinsip ini berlaku pula terhadap perundang-undangan, pengaturan dan persyaratan-persyaratan hukum yang dapat memengaruhi penjualan, pembelian, pengangkutan, distribusi atau penggunaan produk-produk di pasar dalam negeri. Prinsip ini memberikan perlindungan terhadap proteksionisme sebagai akibat upaya-upaya atau kebijakan administratif atau legislatif. ${ }^{30}$

Dengan demikian bahwa prinsip national treatment ini menghindari diterapkannya peraturan-peraturan yang menerapkan perlakuan diskriminatif yang ditujukan sebagai alat untuk memberikan proteksi terhadap produkproduk buatan dalam negeri. Tindakan yang demikian ini menyebabkan terganggunya kondisi persaingan antara buatan dalam negeri dengan barang impor dan mengarah kepada pengurangan terhadap kesejahteraan ekonomi. ${ }^{31}$ Melalui persaingan yang adil antara produk impor dan produk dalam negeri, maka terjadi perbaikan kinerja pada produksi dalam negeri untuk lebih

\footnotetext{
27 John H. Jackson, et.al.,Legal Problem of International Economic Relations, (West Publishing Co., 1995), hlm. 501.

${ }^{28}$ Herman Mosler, The International Society as a Legal Community, (USA: Sijtihoff \& Nordhoff, 1980), hlm. 254.

${ }^{29}$ National Treatment Principle, http://www.meti.go.jp/english/report/gct002e.pdf,

${ }^{30}$ Oliver Long, Law and Its Limitation in the GATT Multilateral Trade System, (Martinus Nijhoff Publisher, 1987), hlm. 9.

${ }^{31}$ National Treatment Principle, Ibid., hlm. 3.
} 
efisien sehingga dapat bersaing dengan produk impor, sedangkan bagi konsumen hal ini akan lebih menguntungkan karena memungkinkan konsumen memperoleh barang yang lebih baik dan harga yang lebih wajar. ${ }^{32}$ Dalam perspektif lain disebutkan bahwa justru tindakan yang demikian dapat menyebabkan kurangnya minat investor untuk menanamkan modalnya, karena berkurangnya keleluasaan investor untuk mengambil keputusan bisnis yang lebih bebas. ${ }^{33}$

Dalam hukum perdagangan internasional, prinsip ini menuntut tidak adanya perlakuan khusus terhadap barang buatan dalam negeri dan larangan adanya perlakuan diskriminatif berdasarkan asal negara. Barang buatan dalam negeri dan barang asal impor diperlakukan sama, demikian pula bahwa perlakuan terhadap semua negara anggota WTO harus sama tanpa ada negara tertentu yang diperlakukan khusus. Prinsip national treatment dalam konteks WTO adalah kewajiban bagi setiap anggota untuk tidak menempatkan barang, jasa atau orang dari anggota WTO lain dalam suatu competitive disadvantage dibandingkan barang, jasa, atau warga negaranya sendiri. ${ }^{34}$

Semula negara-negara membedakan antara masalah perdagangan dari masalah penanaman modal. Mereka mengembangkan ketentuan yang berbeda untuk masing-masing bidang tersebut. Dalam upaya memisahkan masalah perdagangan dengan penanaman modal tersebut, suatu negara harus mampu membedakan antara jasa atau komponen jasa yang hanya dapat diproduksi secara lokal. Sebagai contoh, jasa pemrosesan yang disediakan oleh pusat komputer asing melalui suatu jaringan komunikasi jarak jauh adalah perdagangan karena dibuat di luar negeri. Sedangkan jasa pemrosesan data yang disediakan secara lokal oleh suatu fasilitas pemrosesan komputer yang dimiliki oleh pihak asing adalah kegiatan penanaman modal.

Dengan demikian, bahwa prinsip national treatment ini menghindari diterapkannya peraturan-peraturan yang menerapkan perlakuan diskriminatif yang ditujukan sebagai alat untuk memberikan proteksi terhadap produkproduk buatan dalam negeri. Tindakan yang demikian ini menyebabkan terganggunya kondisi persaingan antara buatan dalam negeri dengan barang impor dan mengarah kepada pengurangan terhadap kesejahteraan ekonomi. ${ }^{35}$

Dengan persaingan yang adil antara produk impor dan produk dalam negeri, maka terjadi perbaikan kinerja pada produksi dalam negeri untuk lebih efisien sehingga dapat bersaing dengan produk impor, sedangkan bagi

32 Mahmul Siregar, Kesepakatan Perdagangan Yang Terkait Dengan Persyaratan Penanaman Modal, (Medan, Univesitas Sumatra Utara, 2005), hlm. 14.

${ }^{33}$ Mahmul Siregar, Ibid., hlm. 14.

${ }^{34}$ Rusli Pandika, Sanksi Dagang Unilateral, Di Bawah Sistem Hukum WTO, Cetakan ke-1, (Bandung,Penerbit PT. Alumni, 2010), hlm. 136.

${ }^{35}$ National Treatment Principle, Ibid., hlm. 3. 
konsumen hal ini akan lebih menguntungkan karena memungkinkan konsumen memperoleh barang yang lebih baik dan harga yang lebih wajar. ${ }^{36}$

Namun demikian, bagi sebagian besar pengusaha kecil domestik akan sulit sekali menghadapi persaingan bebas melawan perusahaan multinasional dengan modal dan sumber dayanya yang tak terbatas, akibatnya banyak perusahaan kecil mengalami kebangkrutan. Maka, jika suatu masyarakat atau bangsa, warganya merasa sistem ekonominya berkembang ke arah yang timpang dan tidak adil, maka aturan mainnya harus dikoreksi agar menjadi lebih adil sehingga mampu membawa perekonomian ke arah keadilan ekonomi dan sekaligus keadilan sosial. ${ }^{37}$

Liberalisasi dalam Undang-Undang Penanaman Modal memberi perlindungan penuh kepada penanam modal asing serta mengurangi sampai sedikit mungkin hak pemerintah negara tuan rumah untuk mengendalikan arus modal asing. Disatu pihak, liberalisasi perdagangan internasional dan penanaman modal asing ini dapat menarik produk-produk Indonesia ke pasar dunia dan dapatkah Indonesia berperan sebagai pelaku dalam perdagangan global yang pemain utamanya adalah perusahaan multinasional. Tetapi di lain pihak, pemerintah sendiri harus memprioritaskan kepentingan pembangunan ekonomi nasionalnya. ${ }^{38}$

Terlepas dari globalisasi dan era pasar bebas yang akan menyerbu masuk ke belahan bumi mana pun, termasuk Indonesia, yang penting adalah semangat penyelenggara negara untuk melakukan kontrol yang intensif dan ketat, baik melalui institusi maupun dalam bentuk regulasi. Jika demikian halnya, niscaya kekhawatiran aparat pemerintah maupun anggota DPR tak akan terjadi bahwa penanam modal asing akan kembali menelan pengusaha lokal, yang mungkin akan terjadi dalam era globalisasi ini, siapa pun yang berduit akan tetap menjadi pemenangnya. Inilah konsekuensi mekanisme pasar.

Liberalisasi perdagangan internasional dan penanaman modal asing yang terdapat dalam GATT/WTO yang telah di implementasikan dengan UU No. 25 Tahun 2007 ini bertentangan dengan prinsip demokrasi ekonomi yang terdapat dalam Pasal 33 Undang-Undang Dasar 1945, karena Demokrasi Ekonomi menghendaki terpenuhinya hak-hak dasar setiap individu tanpa kecuali, sedangkan ketentuan-ketentuan liberalisasi perdagangan yang terdapat dalam GATT/WTO yang dilandasi oleh pemikiran kapitalisme membatasi hak-hak dasar terebut dan hanya mereka

\footnotetext{
36 Mahmul Siregar, Kesepakatan Perdagangan Yang Terkait Dengan Persyaratan Penanaman Modal, (Medan, Univesitas Sumatra Utara, 2005), hlm. 14.

37 Mubyarto, Demokrasi Ekonomi, Demokrasi Industrial Dan Ekonomi Pancasila, Yogyakarta, Kepala Pusat Studi Ekonomi Pancasila UGM, Seminar Bulanan ke-4 PUSTEPUGM, Yogyakarta 6 Mei 2003.

${ }^{38}$ An An Chandrawulan, op. cit., hlm.331.
} 
yang mampu bersaing dapat menikmati keuntungan dari ketentuan-ketentuan perdagangan internasional yang terdapat dalam GATT/WTO tersebut.

Jika kita perhartikan secara sekilas, memang Undang-Undang ini disusun untuk kesejahteraan bangsa dalam hal pengelolaan kekayaan alam sebagaimana diamanatkan didalam pasal 33 UUD 1945. Akan tetapi, apabila kita membedah satu persatu pasal dalam Undang-Undang ini, maka terjadi kejanggalan-kejanggalan dimana Undang-Undang ini justru pro kepada Asing yang menanamkan modalnya di Indonesia dan tidak pro rakyat kecil, atau pengusaha kecil.

\section{Penutup}

Pengaturan kebijakan dan hukum penanaman modal asing diatur melalui UU No. 25 Tahun 2007 yang tidak lagi mengadakan pembedaan antara penanam modal dalam negeri (PMDN) dan penanam modal asing (PMA) yang sebelumnya diatur melalui UU No. 1 Tahun 1967 tentang PMA dan UU No. 6 Tahun 1968 tentang PMDN. Kebijakan penanaman modal yang diatur dalam UU No. 25 Tahun 2007 yaitu dengan memberikan perlakuan yang sama kepada semua penanam modal yang berasal dari negara manapun yang melakukan kegiatan penanaman modal di Indonesia. Selain itu, UU No. 25 Tahun 2007 banyak memberikan fasilitas terhadap penanam modal asing, antara lain pembebasan atau keringanan pajak, repatriasi modal, fasilitas perizinan, dan penyerahan sengketa ke badan arbitrase internasional.

Tetapi sesungguhnya, prinsip-prinsip liberalisasi perdagangan internasional dan penanaman modal asing dalam UU No. 25 Tahun 2007, telah bertentangan dengan prinsip demokrasi ekonomi Pasal 33 UUD 1945, karena demokrasi ekonomi menghendaki terpenuhinya hak-hak dasar setiap individu tanpa terkecuali, sedangkan ketentuan-ketentuan liberalisasi perdagangan yang terdapat dalam WTO yang dilandasi oleh pemikiran kapitalisme membatasi hak-hak dasar tersebut dan hanya mereka yang mampu bersaing dapat menikmati keuntungan dari ketentuan perdagangan internasional WTO.

Sebab itu disarankan bahwa walaupun sudah terikat dengan ketentuan perdagangan internasional yang terdapat dalam WTO, tetapi pemerintah harus tetap mampu menggunakan ketentuan-ketentuan dalam WTO tersebut yang paling menguntungkan untuk dipergunakan dan dimanfaatkan yang sebesar-besarnya bagi kepentingan nasional Indonesia.

Dalam mengeluarkan kebijakan-kebijakan atau peraturan-peraturan, pemerintah Indonesia harus lebih mengutamakan kepentingan masyarakat atau pengusaha dalam negeri khususnya dan kepentingan pembangunan nasional pada umumnya, sebagaimana tujuan negara mencapai masyarakat sejahtera sesuai amanat Pasal 33 UUD 1945. 


\section{Daftar Pustaka}

\section{A. Buku}

Atmasasmita, Romli, 2012. Peran Hakim dalam meningkatkan Profesionalisme Hakim Menuju Peradilan Yang Agung, Makalah Seminar Nasional diselenggarakan IKAHI dalam rangka Ulang Tahun IKAHI ke 59 Tanggal 25 April 2012.

Brewer, Thomas L., and Stephen Young, 1998. The Multinational Investment System and Multinational Enterprises, Oxford: University Press, Oxford.

Budiardjo, Miriam, 2005. Dasar-Dasar Ilmu Politik, Cet, ke 27, Jakarta: PT Gramedia Pustaka Utama.

Chandrawulan, An An., 2011. Hukum Perusahaan Multinasional, Liberalisasi Hukum Perdagangan Internasional dan Hukum Penanaman Modal, cetakan ke-1, Bandung: Penerbit PT, Alumni.

Graham, E.M, and Paul Krugman, 1995. Foreign Direct Investment in The United States, Institute for International Economics, Washington, $3 \mathrm{rd}$ edition.

Hampton, Mark P, and Jasson P. Abbott, 1999. Offshore Finance Centres and Tax Havens: The Rise of Global Capital, London: Mac Millan.

Hartono, Sunaryati, 1972. Beberapa Masalah Transnasional dalam PMA di Indonesia, Bandung: Penerbit Binacipta. , 1982. Hukum Ekonomi Pembangunan Indonesia, Bandung: Penerbit Binacipta.

Hood, Neil, and Stephen Young, 1979. The Economic of Multinational Enterprise, London: Longman.

Jackson, John H, et,al., 1995. Legal Problem of International Economic Relations, West Publishing Co.

Jr, Joseph P. Nye, 2002. The Power of the American Paradox, Oxford: Oxford University Press.

Komar, Mieke, et.al., 1999. Mochtar Kusumaatmadja: Pendidik dan Negarawan, Kumpulan Karya Tulis Menghormati 70 Tahun Prof, DR, Mochtar Kusumaatmadja, SH, LLM, Bandung: Alumni.

Kusumaatmadja, Mochtar, 1976. Fungsi dan Perkembangan Hukum dalam Pembangunan Nasional, Lembaga Penelitian Hukum dan Kriminalogi Fakultas Hukum Universitas Padjadjaran, Bandung: Penerbit Binacipta.

Lev, Daniel S,. 1990. Hukum Dan Politik di Indonesia, Kesinambungan dan Perubahan, Cet I, Jakarta: LP3S.

Lippman, Walter, 1999. Filsafat Publik, Terjemahan dari buku aslinya yang berjudul" The Public Philosophy, oleh A, Rahman Zainuddin, Penerbit Yayasan Obor Indonesia. 
Long, Oliver, 1987. Law and Its Limitation in the GATT Multilateral Trade System, Martinus Nijhoff Publisher.

Mosler, Herman, 1980. The International Society as a Legal Community, USA: Sijtihoff \& Nordhoff.

Mubyarto, 2003. Demokrasi Ekonomi, Demokrasi Industrial Dan Ekonomi Pancasila, Yogyakarta, Kepala Pusat Studi Ekonomi Pancasila UGM, Seminar Bulanan ke-4 PUSTEP-UGM, Yogyakarta 6 Mei.

Nasution, Asmin, 2009. "Penerapan Prinsip Transparansi dalam UndangUndang Nomor 25 Tahun2007 tentang Penanaman Modal Kaitannya dengan Domestic Regulation WTO", Medan: Tesis Magister Univesitas Sumatera Utara.

Pandika, Rusli, 2010. Sanksi Dagang Unilateral, Di Bawah Sistem Hukum WTO, Cetakan ke-1, Bandung,Penerbit PT, Alumni.

Siregar, Mahmul, 2005. Kesepakatan Perdagangan Yang Terkait Dengan Persyaratan Penanaman Modal, Medan: Univesitas Sumatra Utara.

Stiglitz, 2003. Globalization and Its Discontent; Norton and CompanyPaperback.

\section{B. Peraturan Perundang-undangan}

UUD Tahun 1945.

Undang-Undang Nomor 17 Tahun 2007 tentang Pembangunan jangka Panjang.

Undang-Undang Nomor 25 Tahun 2007 tentang Penanaman Modal ( LN No. 67 Tahun 2007, TLN No. 4724).

\section{Lain-lain}

National Treatment Principle, http://www.meti.go.jp/english/report/gct00 2e.pdf. 